\section{Surgical Approach and Clinical Outcome of a Deforming Brown Tumor at the Maxilla in a Patient With Secondary Hyperparathyroidism Due to Chronic Renal Failure}

\begin{abstract}
Brown tumors are relatively uncommon but they are serious complications of renal osteodystrophy. We describe a 31-year-old woman with end-stage renal disease who had undergone hemodialysis for nine years and developed severe secondary hyperparathyroidism and a maxilla brown tumor despite increasing doses of oral calcitriol and calcium carbonate. The fast increase of the right maxillary bone tumor led to indication of parathyroidectomy (PTX). Despite normalization of serum PTH there was a slow regression of the mass and the patient still complained about her appearance after two-years of follow-up. Excision of the maxillary mass followed by recontouring of the maxilla was then performed, with adequate masticator rehabilitation. (Ara Bras Endocrinol Metab 2006;50/5:963-967)
\end{abstract}

Keywords: Brown tumor; Parathyroidectomy

\section{RESUMO}

\begin{abstract}
Abordagem Cirúrgica de um Tumor Marrom Deformante em Maxila Após Paratireoidectomia em Paciente com Hiperparatireoidismo Secundário à Insuficiência Renal Crônica.

Tumores marrons são relativamente incomuns mas constituem sérias complicações da osteodistrofia renal. Descrevemos o caso de uma paciente, 31 anos, com doença renal em estágio terminal, em hemodiálise há nove anos, que desenvolveu severo hiperparatireoidismo secundário com tumor marrom em maxila apesar de doses crescentes de calcitriol oral e carbonato de cálcio. O rápido aumento do tumor marrom em maxila levou à indicação de paratireoidectomia (PTx). Apesar da normalização dos níveis de PTH sérico, a regressão da massa tumoral foi lenta e a paciente questionava sobre sua aparência após dois anos de seguimento. A excisão da massa maxilar foi seguida da reconstrução com adequada função mastigatória. (Arq Bras Endocrinol Metab 2006;50/5:963-967)
\end{abstract}

Descritores: Tumor marrom; Paratireoidectomia

B ROWN TUMORS ARE EROSIVE bony lesions caused by rapid osteoclastic activity and peritrabecular fibrosis due to hyperparathyroidism (HPT) resulting in a local destructive phenomenon. Actually they represent a reparative cellular process rather than a true neoplasia $(1,2)$. They are known to occur only in the setting of HPT, and are considered the most pathognomonic skeletal changes that accompany this disease. For years, these lesions have been recognized in primary hyperparathyroidism (HPTl) (3). However, brown tumors have also been reported in patients with severe hyperparathyroidism secondary to chronic renal failure (HPT2), especially those on long-term hemodialysis $(4,5)$.

\section{apresentação de caso}

Christianne T.S. Leal

Paulo G.S. Lacativa

Elaine M.S. Gomes

Reinaldo C. Nunes

Flávio Luiz F. de S. Costa

Italo H.A. Gandelmann

Maria A.A. Cavalcante

Maria Lucia F. Farias

Department of Endocrinology and Department of Oral and Maxillofacial Surgery, University Hospital Clementino Fraga Filho, Federal University of Rio de Janeiro, RJ, Brazil. 
A brown tumor is usually painless and need no specific treatment in most cases. However, it can provoke pathological fractures and even spinal cord compression when it involves the spinal column (1). Moreover, when it affects the face, it can cause disfiguring deformities and difficulties to breathe through the nose or to eat $(4,6)$.

Here we present a patient with brown tumor of the maxilla provoked by HPT2 and its response to the decrease in PTH levels after parathyroidectomy (PTx) and local surgery. The management of that uncommon condition is reviewed.

\section{CASE REPORT}

A 31-year-old black woman was referred to our ambulatory from a dialysis clinic for investigation of HPT2. She had a nine-year history of hemodialysis-dependent anuric renal failure of undetermined cause. During the last five years parathyroid hormone circulating levels were very high (intact PTH always above $2500 \mathrm{pg} / \mathrm{ml}$ for a normal range of 12 a $72 \mathrm{pg} / \mathrm{ml}$ ) refractory of clinic treatment, which included calcitriol pulsotherapy, and led to severe hyperparathyroid bone disease and brown tumors. Eight months before the first visit, a tumor in right maxillary region became evident and was increasing very fast since then, leading to progressive difficulty to swelling, eating and breathing through the nose. On initial examination, she was unable of walking without help, restricted to a wheel chair, and also complained about diffuse bone pain. She had skeletal deformities - kyphoscoliosis and resorption of the distal phalanges of the fingers. A bone biopsy performed two years ago had shown intense osteitis fibrosa cystica, high bone turnover and negative for aluminum intoxication. Bone mineral density was then evaluated by DEX, Lunar Corporation, showing a whole-body T-score of -4.5 and a $\mathrm{Z}$ score of -2.4 .

She was taking captopril $50 \mathrm{mg} 2 \mathrm{x} /$ day, hydralazyne $50 \mathrm{mg} 3 \mathrm{x} /$ day, propranolol $10 \mathrm{mg} 2 \mathrm{x} /$ day, calcium carbonate $7 \mathrm{~g} /$ day, calcitriol $2.5 \mu \mathrm{g} /$ day, recombinant human erythropoietin and ferrous sulfate. Her routine laboratorial exams were as follows: PTH $3086 \mathrm{pg} / \mathrm{mL}$ (7-53), calcium $8.4 \mathrm{mg} / \mathrm{dL}(8.5-10.1)$, phoshporus $7.1 \mathrm{mg} / \mathrm{dL}(2.5-4.9)$, alkaline phosphatase $1333 \mathrm{U} / \mathrm{L}(50-136)$, sodium $136 \mathrm{mEq} / \mathrm{L}$ (135-145), potassium $5.8 \mathrm{mEq} / \mathrm{L}(3.5-4.5)$, urea $178 \mathrm{mg} / \mathrm{dL}(20-40)$, creatinine $8.6 \mathrm{mg} / \mathrm{dL}$ (0.7-1.2), hemoglobine $8.6 \mathrm{~g} / \mathrm{dl}(14-18)$ and hematocrit $17.8 \%(37-48)$.
The rapid growth of the maxillary lesion dictated the need for immediate resolution of the HPT2. She was submitted to total PTx, with heterotopic autotransplantation (resection of all parathyroids and implant of $1 / 3$ of the inferior parathyroid divided in minifragments in the right forearm muscle) at the same month of her initial visit. It was necessary to perform orotraqueal intubation with fiberoptic broncoscope due to the maxillary mass. As a hungry bone syndrome was expected, a continuous infusion of intravenous calcium was maintained for two days and the patient did not manifest clinical signs of hypocalcemia. She left hospital on the third day receiving $8 \mathrm{~g}$ of oral calcium carbonate and $0.25 \mu \mathrm{g}$ of calcitriol daily.

In the post-operative period, PTH levels decreased towards normal values and the parathyroid implanted worked well. The diffuse bone pain disappeared and the patient could walk again. The maxillary brown tumor stopped its progression and even decreased in size, allowing the patient to breath and feed without difficulties. One year after PTx, exams were as follows: PTH $105 \mathrm{pg} / \mathrm{mL}$ (7-53), calcium 8.7 $\mathrm{mg} / \mathrm{dL}(8.5-10.1)$, phosphorus $3.4 \mathrm{mg} / \mathrm{dL}(2.5-4.9)$, alkaline phosphatase $460 \mathrm{U} / \mathrm{L}$ (50-136), hemoglobine $9.2 \mathrm{~g} / \mathrm{dl}(14-18)$ and hematocrit $28.3 \%(37-48)$. The bone densitometry repeated one year after PTx demonstrated an increase of $40.8 \%$ in the bone mineral density in the head, contrasting with an increase of $23.3 \%$ in the whole body. Two years after PTx the mass was still decreasing in size, but very slowly and the patient complained about her appearance. It was then decided to perform a local excision of the mass. The surgery was planned after routine exams, computed tomography scans of the face (figurel) and angiograph scans of extern carotid artery. Surgery occurred under general anesthesia and the surgeons chose the classic Liston incision that allows intra and extra oral view of the lesion (figure 2). The lesion was histopathologically considered a brown tumor. After the surgical treatment there was a good improvement in the patient's appearance and in the ability to eat.

\section{DISCUSSION}

Chronic hyperparathyroidism directly affects the bone, enhancing its mobilization by increased osteoclastic bone resorption. Most patients with CRF present some degree of secondary hyperparathyroidism and modifications of parathyroid glands begin early during the development of the renal disease (7). In very se- 


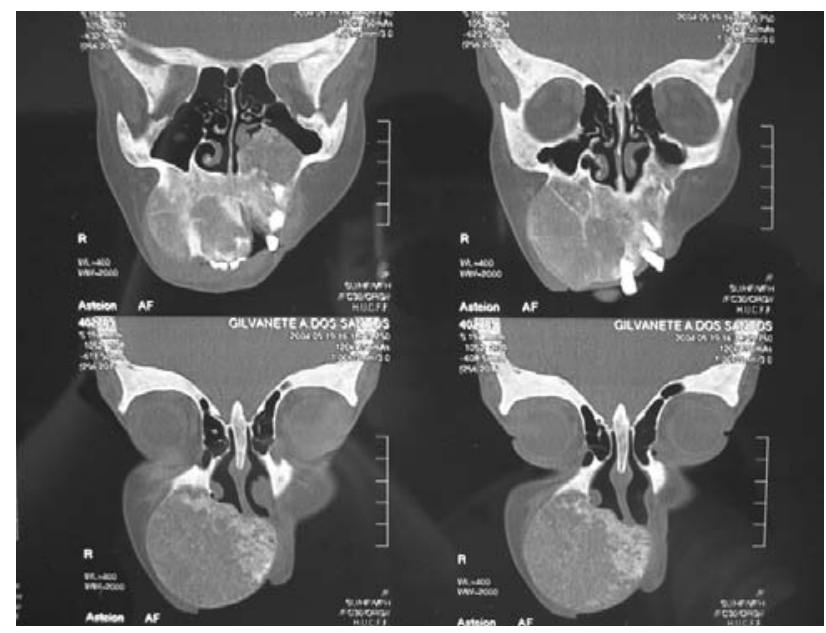

Figure 1. Axial View of Computed Tomograph scans brought with the patient days before the surgery.

vere cases, generalized fibrous cystic osteitis develops due to increased resorption of periosteal and endosteal surfaces, pathologic fractures and brown tumors $(8,9)$. The incidence of skeletal brown tumors in CRF ranges from 1.5 to $13 \%$, but is expected to decrease with improvements in the medical care of these patients $(1,8)$. This unusual complication of HPT2 is more commonly seen in young female patients, with increased longevity of hemodialysis, as was the case of our patient $(6,10)$. Brown tumors can occur as solitary or multiple lesions in any bone, most often in the pelvis, ribs, clavicle, mandible and the extremities (1012). Involvement of the column (1) and the maxillary is considered rare $(10,13)$, although this latter localization has been increasingly reported over recent years (10). These tumors are usually soft, painless, minimally tender, and appear elastic on palpation (8). Histologically, brown tumors are made up by a cell population consisting of mononuclear stromal cells, mixed with multinucleated giant cells (16). Symptoms result from the considerable dimensions of the tumor and its localization, but in most cases maxillary tumor is not painful. When a brown tumor involves the face and has progressive growth, it may cause severe deformities, discomfort, alteration of the masticatory apparatus, difficulty to breathe through the nose or to eat, as demonstrated in the case here reported $(4,10)$.

On imaging examination, brown tumors are usually well-defined purely lytic lesions that stimulate little reactive bone formation $(4,14)$. The cortex may be thinned and expanded, but is not often penetrated. Attenuation values observed on tomography (CT) scans usually fall within the range found in blood and fibrous tissues.

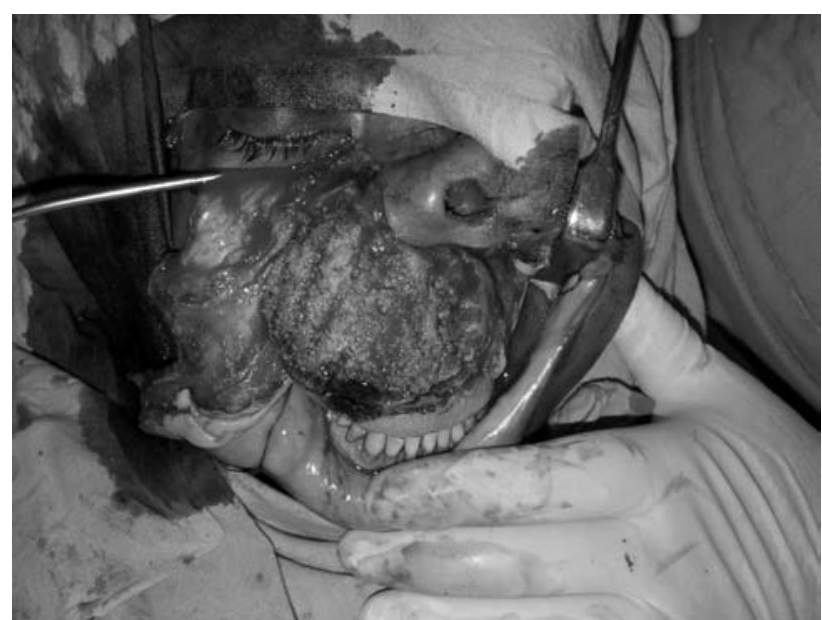

Figure 2. The bone cavity obtained during the surgical ressection of the maxilla brown tumor.

With respect to diagnostic criteria by magnetic resonance image (MRI), the lesions exhibit low signal intensity on T1 and T2 weighted images, with foci of increased intensity corresponding to spots of hemorrhage. They display homogeneous enhancement following administration of contrast agent, and there are multiple foci of low signal intensity $(8,14)$. Biopsy of the lesion is not necessary in CRF, since the clinical history of HPT2 usually establishes the diagnosis (1). In HPTl there is a need for biopsy, especially because the brown tumor could be the first manifestation of the disease $(15,16)$.

Patients with brown tumors are typically treated by medical management for their HPT2. The goals of prevention and treatment of these tumors in patients with CRF include normalizing blood levels of calcium and phosphate with phosphate binders, calcium and 1,25 dihydroxyvitamin D. Few cases of brown tumors are described in patients successfully treated with high doses of vitamin $\mathrm{D}(4,17,18)$. Garcia et al. reported a patient with maxillary brown tumor with great improvement 19 months after high dose of oral calcitriol (19).

However, patients with very severe HPT2 may be unresponsive to high-dose vitamin $\mathrm{D}$ and require PTx, like the patient described in this article. The decrease in size and the healing of such lesions with sclerosis is usually fast after the removal of the parathyroids (4). PTx isolated was able to halt the progression of the brown tumor in many cases and even lead to its disappearance $(1,4,7)$. Rarely new lesions appear or progress following PTx (8). An exception was a case described by Menard et al. that presented a rapid growth of the mandibular tumor eleven days after subtotal PTx; this unusual evolution has justified a 
local excision of the tumor (20). Krause et al. reported a case with rapidly growing maxillary mass leading to severe eating and speech disabilities, which did not respond to the successful control of PTH levels achieved by vitamin $\mathrm{D}$ pulse therapy, and had to be surgically excised (21). Morrone et al. (4) described a case in which the rapid growth of the maxillary lesion dictated the need for immediate resolution of the HPT2. Therefore surgical PTx is considered as the most adequate therapeutic approach in patients with unsatisfactory response to calcitriol, and a progressive regression of the bone tumors is expected. Repeated CT scan shows this progressive decrease in the size of the tumors, and refilling of the lesions by calcified material (14). Our patient had bigger increase in bone density of the head as compared to the whole body and it can, probably, be explained by the tumor mineralization.

Although PTx is considered to be curative, surgical removal of the bone tumoral mass may sometimes be required (22) due to persistence of the lesion or the large destructive size. In certain anatomical sites, decompression of the brown tumor is urgently needed because these lesions expand and can cause local destruction. This is particularly true for maxillary lesions, which may lead to serious deformities of the face and even a lethal outcome (4). The radical resection of a brown tumor of the palate or maxilla has several problems. After maxillectomy, it is necessary to apply an obturator prosthesis. Additional dental treatment followed by recontouring of the maxilla and mandible is often necessary. A 3-D reconstruction of the computed tomography scan can be helpful in evaluating the facial deformities and in treatment planning (23).

In conclusion, brown tumors can be rapidly evolving lesions whose regression may be very low or not occur even after total PTx, especially lytic lesions in the maxilla. The choice of treatment must be oriented towards PTx and, if necessary, resection of these tumors.

\section{REFERENCES}

1. Fineman I, Johnson $\mathrm{P}$, Di-Patre $\mathrm{PL}$, Sandhu H. Chronic renal failure causing brown tumors and myelopathy. $J$ Neurosurg 1999:90(Spine2):242-6.

2. Wyngaarden JB, Smith LH, Cecil RL. Cecil texbook of medicine. $19^{\text {th }}$ ed. Philadelphia: WB Saunders, 1992. pp. 1409-26.

3. Marcos GM, Pino RV, Keituqwa YT, Alcaraz FM, Trinidad $R G$, Blasco HA. Brown bone tumor as the first manifesta- tion of primary hyperparathyroidism. Acta Otorrinolringol Esp 2003;54:470.

4. Morrone LF, Ettore GC, Passavati G, Tampoia M, Schiavone $\mathrm{P}$, Coratelli P. Maxillary brown tumor in secondary hyperparathyroidism requiring urgent parathyreoidectomy. J Nephol 2001;14:415-9.

5. Nassar MG, Ayus JC. Brown tumor in end-stage renal disease. N Engl J Med 1999;341:1652.

6. Tarello F, Ottone S, De Gioanni PP, Berrone S. Brown tumor of the jaws. Minerva Stomatol 1996:45:465-70.

7. Tominaga $Y$. Parathyroidectomy for patients with renal osteodystrophy. Clin Calcium 2003; 13:340-3.

8. Al-Gatany M, Cusimano M, Singer W, Bilbao J, Kovacs K, Marotta T. Brown tumors of the skull base. J Neurosurg 2003:98:417-20.

9. Chew FS, Huang-Hellinger F. Brown tumor. AJR 1993; 160:752.

10. Pinar Sumer A, Arik N, Sumer M, Karagoz F. A rare complication of secondary hyperparathyroidism. Brown tumor of the maxilla and mandible. Saudi Med J 2004:25:2010-20.

11. Peces R, Gil F, Gonzalez F, Ablanedo P. Multiple brown tumors in female hemodialyzed patient with severe secondary hyperparathyroidism. Nefrologia 2002;22:79-82.

12. Daniels JSM; BDS, FDSRCS (Eng), FFDRCS (Ire). Primary hyperparathyroidism presenting as a palatal brown tumor. Oral Surg Oral Med Oral Pathol Oral Radiol Endod 2004:98:409.

13. Andreades D, Belazi M, Antoniades D. Diagnosis of a maxillary brown tumor associated with hyperparathyroidism secondary to chronic renal failure - a case report. Oral Health Prev Dent 2004;2:143-7.

14. Takeshita T, Tanaka $H$, Harasawa A, Kaminaga T, Imamura T, Furui S. Brown tumor of the sphenoid sinus in a patient with secondary hyperparathyroidism: CT and MR imaging findings. Radiat Med 2004;22:265-8.

15. Morano S, Cipriani R, Gabriele A, Médici F, Pantellini F. Recurrent brown tumors as initial manifestation of primary hyperparathyroidism: An unusual presentation. Minerva Med 2000;91:117-22.

16. Fernandez-Sanroman J, Anton-Badiola IM, Costas-Lopez A. Brown tumor of the mandible as first manifestation of primary hyperparathyroidism: diagnosis and treatment. Med Oral Patol Oral Cir Bucal 2005; 10:169-72.

17. Buchwald PC, Westin $G$, Akerstrom $G$. Vitamin D in normal and pathological parathyroid glands: new prospects for treating hyperparathyroidism (review). Int J Mol Med 2005: 15:701-6.

18. Francisco AL. Secondary hyperparathyroidism: review of the disease and its treatment. Clin Ther 2004:26:1976-93.

19. Garcia GM, Leanza H, Najun ZC, Barreneche M. Medical parathyroidectomy. Its efficacy in treatment of lower maxillary brown tumor. Medicina B Aires 1996;56:59.

20. Menard P, Pauzie F, Philippe B, Bertrand JC. A brown tumor of the mandible and hyperparathyroidism secondary to chronic renal insufficiency. Review of the literature apropos of a case. Ver Stomatol Chir Maxillofac 1993; $94: 276-80$.

Arq Bras Endocrinol Metab vol 50 n 5 Outubro 2006 
21. Krause I, Eisenstein B, Davidovits $M$, Cleper R, Tobar A, Calderon S. Maxillomandibular brown tumor - a rare complication of chronic renal failure. Pediatr Nephrol 2000; 14:499-501.

22. Balon BP, Kavalar R. Brown tumor in association with secondary hyperparathyroidism. Am J Nephrol 1998; 18:460.

23. Michiwaki Y, Michi K, Yamaguchi A. Marked enlargement of the jaws in secondary hyperparathyroidism - a case report. Int J Oral Maxillofac Surg 1996;25:54-6.

\section{Endereço para correspondência:}

Christianne Tolêdo de Souza Leal

Rua Marechal Mascarenhas de Morais 190/201

22030-040 Rio de Janeiro, RJ

E-mail: christianneleal@terra.com.br 